\title{
Topical Niosome Gel of Zingiber cassumunar Roxb. Extract for Anti-inflammatory Activity Enhanced Skin Permeation and Stability of Compound D
}

\author{
Aroonsri Priprem, ${ }^{1,5}$ Khwanhatai Janpim, ${ }^{2}$ Somsak Nualkaew, ${ }^{3}$ and Pramote Mahakunakorn ${ }^{4}$
}

Received 16 April 2015; accepted 20 July 2015; published online 21 August 2015

\begin{abstract}
An extract of Zingiber cassumunar Roxb. (ZC) was encapsulated in niosomes of which a topical gel was formed. (E)-4-(3',4'-dimethoxyphenyl)but-3-en-1-ol or compound D detected by a gradient HPLC was employed as the marker and its degradation determined to follow zero-order kinetics. Niosomes significantly retarded thermal-accelerated decomposition of compound $\mathrm{D}$ in the gel $(p<0.05)$ but did not change the activation energy of compound $\mathrm{D}$. Niosomes enhanced in vitro permeation rate of compound $\mathrm{D}$ from the gel. Topical applications of ZC noisome gel gave a faster change in tail flick latency than piroxicam gel and hydrocortisone cream $(p<0.05)$ while there were insignificant differences in antiinflammatory activity up to $6 \mathrm{~h}$ using croton oil-induced ear edema model in mice $(p>0.05)$. Thus, encapsulation of ZC extract in niosomes enhanced chemical stability and skin permeation with comparable topical anti-inflammatory effects to steroid and NSAID.
\end{abstract}

KEY WORDS: Activation energy; Compound D; Niosomal gel; Topical anti-inflammatory; Zingiber cassumunar.

\section{INTRODUCTION}

Niosomes, small bilayer-structured vesicles usually composed of non-ionic synthetic surfactants, are capable of functioning as depots which improve skin delivery of the encapsulated substances (1-5) including phytochemicals (68). Niosomal gel is usually composed of three-dimensional polymeric networks of hydrogels (9) capable of imbibing water which embeds the niosomes, thus making feasible skin applications for desirable local effects. Topical delivery and local accumulation of anti-inflammatory drugs have been shown to be improved by niosomal gels (10-13).

Rhizomes of Zingiber cassumunar Roxb. (ZC), family Zingiberaceae, are usually applied topically onto the skin in Thai traditional medicine and spa treatment to alleviate

Electronic supplementary material The online version of this article (doi:10.1208/s12249-015-0376-z) contains supplementary material, which is available to authorized users.

${ }^{1}$ Division of Pharmaceutical Technology, Faculty of Pharmaceutical Science, Khon Kaen University, Khon Kaen, 40002, Thailand.

${ }^{2}$ Program in Pharmaceutical Chemistry and Natural Products, Faculty of Pharmaceutical Science, Khon Kaen University, Khon Kaen, 40002, Thailand.

${ }^{3}$ Division of Pharmacognosy and Medicinal Chemistry, Faculty of Pharmacy, Mahasarakham University, Mahasarakham, 44150, Thailand.

${ }^{4}$ Division of Toxicology, Faculty of Pharmaceutical Science, Khon Kaen University, Khon Kaen, 40002, Thailand.

${ }^{5}$ To whom correspondence should be addressed. (e-mail: apriprem@gmail.com) musculoskeletal pain, rheumatism, and localized inflammation (14-18). (E)-4-(3,4-dimethoxyphenyl)but-3-en-1-ol, compound D, one of the pharmacologically active phenylbutanoids from ZC, exerts anti-inflammatory action $(19,20)$ via cyclooxygenase inhibition and antioxidation $(21,22)$ with cytochondroprotective activities which are advantageous for the treatment of arthritis (23-26). Topical products of ZC are generally prepared in emulsions or gels (27-29) from crude extracts which provide greater anti-inflammatory potency than its isolated components (21). Compound D from an alcoholic extract of ZC in a hydrogel skin patch was shown to be rapidly released, permeated through the skin with local accumulation (20). Curcumin, one of the well-studied phytochemicals, is shown to stabilize in the bilayer of niosomes by intermolecularly associating with the hydroxyl groups of cholesterol (30). The chemical structure of compound D (MW $208 \mathrm{~g} / \mathrm{mol})$ is smaller but similar to curcumin $(368 \mathrm{~g} / \mathrm{mol})$; thus, it is potentially encapsulable in niosomes.

If niosomes could encapsulate phytochemicals extractable from $\mathrm{ZC}$ and be formulated into a niosomal gel, it is proposed that permeation and stability of compound $\mathrm{D}$, employed as the representative marker, should be improved. Thus, if ZC niosomal gel improved in vitro skin permeation and thermal-accelerated stability of compound D, it would be compared with commercially available preparations in in vivo anti-inflammatory tests.

\section{MATERIALS AND METHODS}

Sorbitan monostearate (Span 60), croton oil, propylene glycol, polyethylene glycol 400 (PEG) and polyvinyl alcohol 
(PVA) from Sigma-Aldrich (USA); acetonitrile (HPLC grade) and methanol (HPLC grade) from Merck (Germany); acetic acid, triethanolamine (TEA), sodium borate, acetone and acetic acid from BDH Laboratory Supplies (England); and carbomer (Carbopol 940) from Librizol (the People's Republic of China) were used as received.

Phosphate buffer saline (PBS, Lonza, USA), disposable syringes with hypodermic thin-wall needles $(0.8 \times 25,0.7 \times 40$ and $0.55 \times 25 \mathrm{~mm}$, Nipro ${ }^{\circledR}$, Thailand), aluminium collapsible tubes $(1.25 \mathrm{~mm}$ in diameter and $10 \mathrm{~cm}$ in length, N.R. Rama Co. Ltd., Thailand), 1\% hydrocortisone cream (ATC, Thailand), $0.5 \%$ piroxicam gel (General Drugs House Co. Ltd., Thailand) and pentobarbital sodium (Nembutal ${ }^{\circledR} 5.47 \mathrm{~g} /$ 100 ml, CEVA Sante Animal, France) were used as received.

\section{Z. cassumunar: Preparation, Extraction and Separation}

Cultivation could have effects on the quality of $\mathrm{ZC}$ $(21,22)$; thus, fresh rhizomes of $Z$. cassumunar from local farms were collected from 12 to 18 months old (about $300 \mathrm{~g}$ / piece) with dark brown peel and yellowish bulk. The rhizomes were peeled, sliced, dried $\left(50 \pm 1^{\circ} \mathrm{C}, 3\right.$ days $)$ and ground into ZC powder.

\section{HPLC Analysis of Compound D}

A gradient RP-HPLC system for determination of compound D was adopted $(18,20,27,31)$. In brief, a gradient solvent system composed of $0.2 \%$ acetic acid in water (A) and acetonitrile (B) was varied from $70,65,55,50$ and $100 \%$ of $\mathrm{A}$ for 0-5, 5-10, 10-20, 20-30 and $\geq 30 \mathrm{~min}$, respectively, through a RP-C $\mathrm{C}_{18}$ column $(5 \mu \mathrm{m}, 250 \times 4 \mathrm{~mm}$, Phenomenex, Japan $)$ at a flow rate of $0.8 \mathrm{ml} / \mathrm{min}$ and detection at $254 \mathrm{~nm}$. The HPLC validation of compound $\mathrm{D}$ determined limits of detection and quantitation of compound D of about 0.04 and $0.42 \mu \mathrm{g} / \mathrm{ml}$, respectively, good accuracy (96.20-104.25\%), precision (a coefficient of variation of less than $3.5 \%$ ) and linearity with good correlation coefficient $(r) \geq 0.998$ in the required concentration range of $1-10 \mu \mathrm{g} / \mathrm{ml}$. Compound D was separated from $n$ hexane extract of ZC powder by column chromatography and eluted with a hexane-ethyl acetate gradient system followed by several more chromatograph separations on fresh silica gel columns by following a previously described method (31).

\section{Preparation of ZC Niosomal Gel and ZC Gel}

ZC powder was extracted by methanol (1:10) and filtered for ZC liquid extract which was then dried and re-dissolved with a solvent mix (ethanol/propylene glycol/water at a volume ratio of 5:14:6). PVA gel was prepared by dissolving in deionized water at a concentration of $3 \% \mathrm{w} / \mathrm{v} .1 .6 \% \mathrm{w} / \mathrm{v}$ carbomer gel was prepared in deionized water by adding $0.5 \%$ of TEA. The PVA gel was thoroughly mixed with the carbomer gel at a respective weight ratio of 1 to 5 to form the blank gel (the viscosity of $8-10 \times 10^{3}$ poise at $25^{\circ} \mathrm{C}$ ). $\mathrm{ZC}$ niosomes were prepared by mixing $0.5 \%$ of span $60,0.5 \%$ of cholesterol, $0.5 \%$ of sodium deoxycholate, $56 \%$ of propylene glycol with $42 \%$ of the ZC liquid extract and $0.5 \%$ of water with intermittent sonication for $15 \mathrm{~min}$.

ZC gel, blank niosomal gel or ZC niosomal gel were formed by thoroughly mixing the $\mathrm{ZC}$ extract, blank niosomes or ZC niosomes, respectively, with the blank gel (2:5). The gel was filled in laminated collapsible aluminium tubes in which air volume was kept minimal. Visual observations by scanning electron microscope (SEM, Leo 1450, Germany) of ZC niosomal gel were conducted after diluting, mounting, drying and gold stubbing samples on a glass slide.

\section{Stability Testing}

Freshly prepared ZC gel or ZC niosomal gel (about 100 tubes/batch, three batches) was randomly assigned to four storage temperatures, $4,25,45$ and $50^{\circ} \mathrm{C}$ at $70-75 \% \mathrm{RH}$. At predetermined times, two tubes of each set were sampled from the top, middle and end of each. The samples were diluted with methanol prior to being analysed by HPLC. The average compound D remaining in both gels versus storage durations were analysed for best fitted correlation from which the degradation kinetics and rates were derived. Their activation energies $\left(E_{\mathrm{a}}\right)$ were calculated from the slopes of the regression analyses using the Arrhenius equation (32), as follows:

$\ln k=\ln A-\frac{E_{\mathrm{a}}}{R T}$

where $k=$ degradation rate constant, $A=$ exponential factor, $E_{\mathrm{a}}=$ activation energy, $R=$ gas constant and $T=$ absolute temperature (Kelvin). Stored gel and niosomal gel bases were monitored and found no peak or change.

\section{In vitro Permeation Test}

Immediately after sacrifice, full-thickness skin was excised from the dorsal part of five newborn pigs after soaking in normal saline solution at $60^{\circ} \mathrm{C}$ for $45 \mathrm{~s}(33,34)$. The skin (thickness $\sim 0.2 \mathrm{~mm}$ ) was mounted between donor and receptor chambers of an amber-glass 10-ml Franz diffusion cell (Crown Glass Company, USA) facing the exterior side to the donor and $0.1 \%$ albumin solution $(\mathrm{pH} 7.4)$ as the receptor fluid $\left(35 \pm 1^{\circ} \mathrm{C}, 600 \mathrm{rpm}\right)$. ZC gel or niosomal gel was applied onto the skin. Blank gel and blank niosomal gel were conducted and found no peak. The receptor fluid was sampled for HPLC analysis, and fresh receptor medium was replaced. Permeation rates of compound $\mathrm{D}$ were obtained by analyzing the data with Fick's law of diffusion.

\section{Anti-inflammation and Analgesic Test in Animal Models}

The Institutional Animal Ethics Committee approved the protocol (no. AEKKU 83/2556) and monitored the research conduct in full compliance with international expectations for animal care and use (35). Male ICR mice (20-40 g) from the National Laboratory Animal Center, Mahidol University, Thailand, were handled by trained personnel and caged in a controlled heating ventilating and air conditioning system at the Northeast Laboratory Animal Center as follows: 12/12-h light/dark cycle, $22-24^{\circ} \mathrm{C}, 50-70 \% \mathrm{RH}$, housed six mice per cage with full labels and free access to food and water. Mice were randomly assigned into groups ( $n=6$ each), as follows: a negative control group (blank), a treatment group (ZC niosomal gel) and two positive control groups $(0.5 \%$ piroxicam gel and $1 \%$ hydrocortisone cream). 
Table I. Compound D Contents in Samples of Rhizomes of Z. cassumunar (ZC) and Products

Z. cassumunar rhizomes (ZC) Compound D (mg/g)

Dried powder ( $n=12$ from 2 lots*) $149.5 \pm 9.1$

$\mathrm{ZC}$ gel $(n=6,106 \%$ recovery) $2.2 \pm 0.1$

ZC noisome gel ( $n=6,105 \%$ recovery) $1.9 \pm 0.5$

$\mathrm{NB} *$ lot 1 was harvested in dry season (the end of February) and lot 2 in rainy season (the end of May)

Ear edema was induced by applying $0.075 \mathrm{mg}$ of croton oil (diluted in acetone) to about $1 \mathrm{~cm}^{2}$ on the posterior part of the right ear, while the left ear received acetone alone. After evaporation of the acetone, $0.1 \mathrm{~g}$ of the assigned treatment was topically applied onto the same area. Ear thicknesses were determined by a digital vernier caliper (Digimatic, Mitutoyo, Japan) and used to estimate ear edema inhibition between treated and non-treated areas (36).

Tail flick test started $30 \mathrm{~min}$ after applying $0.1 \mathrm{~g}$ of the assigned preparation onto about $5 \mathrm{~cm}$ in length of the distal part of the tail of each mouse and wiping off excess. Tail flick latency was measured as the time tails contacted water at $50 \pm$ $1^{\circ} \mathrm{C}$. Screening was performed to include only mice with baseline latency within a range of 4-7 s. Changes in tail flick latency were determined in comparison to data obtained from the relevant negative control group (37).

\section{Statistical Analysis}

Results were expressed as mean \pm standard deviation. Student's $t$ test was used to compare significance of data between the two groups, while analysis of variance (ANOVA) and post hoc least significant difference (LSD) tests were used for
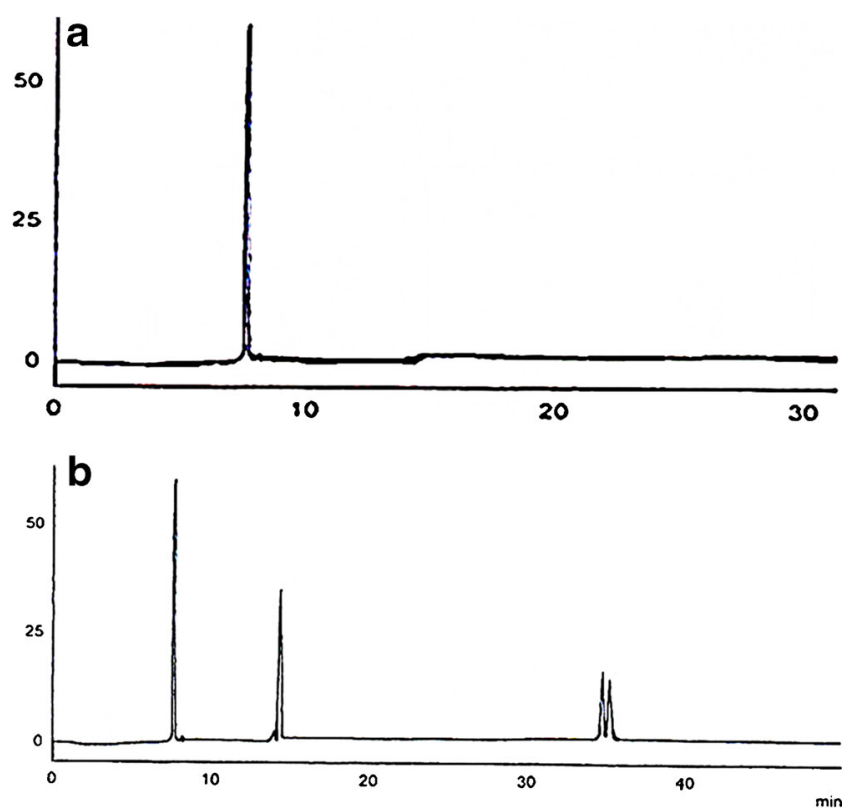

Fig. 1. HPLC chromatograms of a compound D with its chemical structure, and $\mathbf{b}$ methanolic extract of $Z$. cassumunar (detection at $254 \mathrm{~nm}, 250 \times 4 \mathrm{~mm}$ column, gradient between $0.2 \%$ acetic acid in water (a) and acetonitrile (b) from 70, 65, 55, 50 and 100\% of A for $0-5,5-10,10-20,20-30$ and $>30 \mathrm{~min}$, respectively, at a flow rate of $0.8 \mathrm{ml} / \mathrm{min}$ and detection at $254 \mathrm{~nm}$
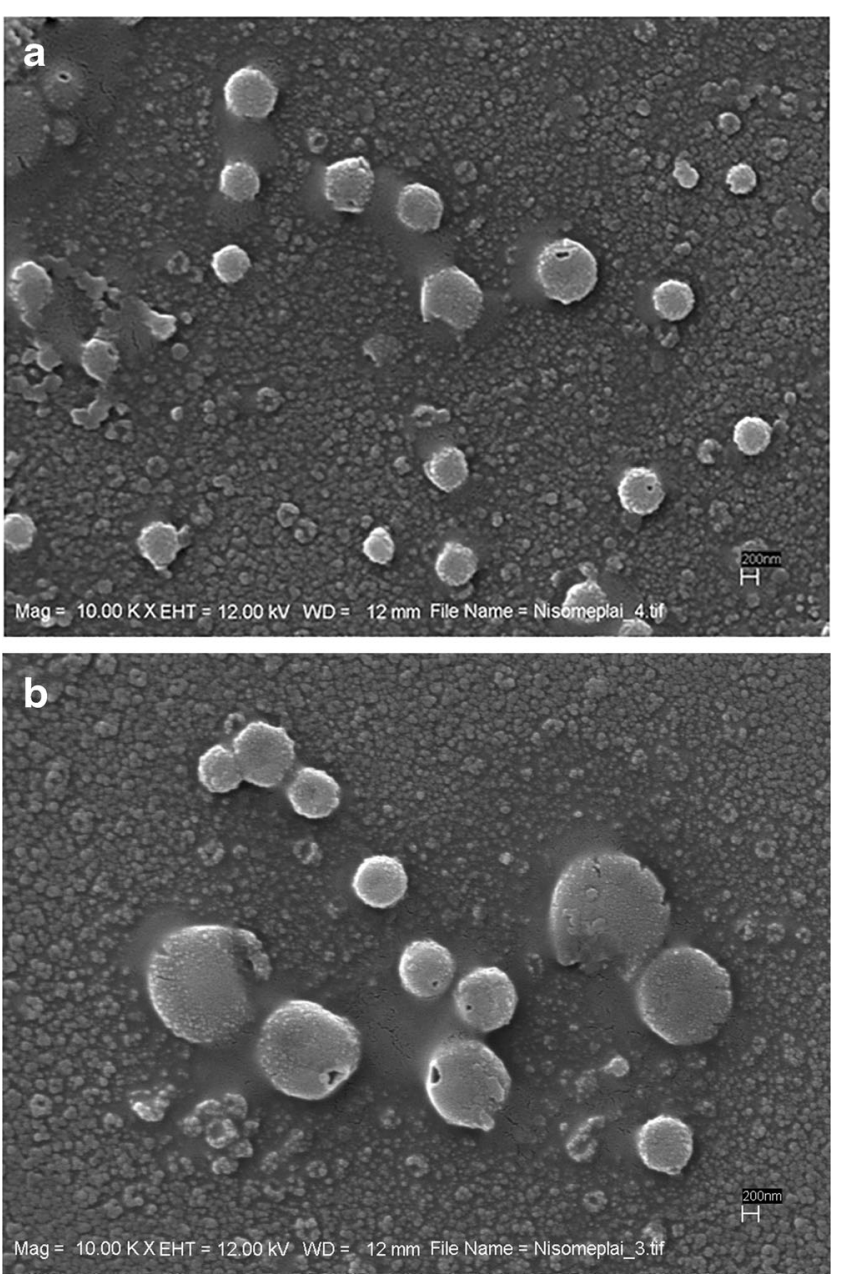

Fig. 2. Scanning electron microscopic photograph of $\mathrm{ZC}$ niosomal gel (a) freshly prepared (b) and stored at $50^{\circ} \mathrm{C} 70-75 \% \mathrm{RH}$ for 60 days $(10,000$ dilution in water) magnification $10,000 \times$

comparisons of $>2$ groups. Significances were considered at $p$ values of $<0.05$.

\section{RESULTS}

The yields of compound D, collected within the same northeast area in Thailand, from dry and rainy seasons were 153.2 and $145.7 \mathrm{mg} / \mathrm{g}$, respectively, which were insignificantly different $(p>0.05)$, as shown in Table I. A representative chromatogram of compound D, shown in Fig. 1a and that of the ZC liquid extract, shown in Fig. 1b, indicate that compound $\mathrm{D}$ can be determined by the HPLC. The colour of ZC liquid extract and ZC gel was deep yellow with a strong camphoraceous smell. ZC niosomal gel was pale yellow with less smell. Both gels were viscous and easily spreadable on the skin. SEM of ZC niosomal gel showed characteristics of spherical particles of niosomes evenly distributed in water, as shown in Fig. 2a. Particle size estimation from visual scale measurement of ten frames of the SEM photographs taken from randomized samples ( $n=6$ each) indicates an average particle size of $1302 \mathrm{~nm}\left(P_{0.1}=690 \mathrm{~nm}\right.$ and $\left.P_{0.9}=1930 \mathrm{~nm}\right)$ which could be due to the interference of the gel which surrounded the 


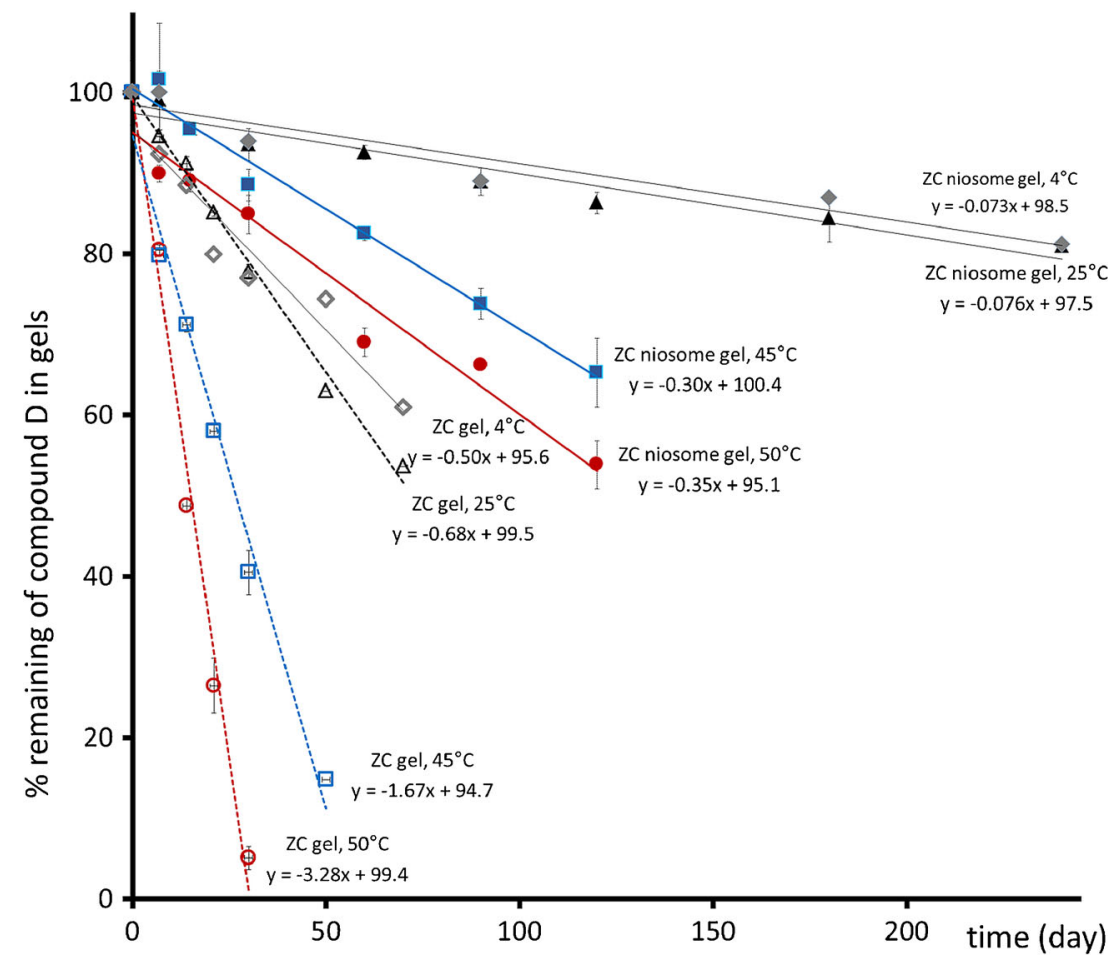

Fig. 3. Comparison of percentage of compound $\mathrm{D}$ remaining in $\mathrm{ZC}$ gel (dashed lines) and $\mathrm{ZC}$ niosomal gel (solid lines) upon storage in collapsible tubes at $4^{\circ} \mathrm{C}($ grey $), 25^{\circ} \mathrm{C}$ (black), $45^{\circ} \mathrm{C}$ (blue) and $50^{\circ} \mathrm{C}($ red $)$

particles. Figure $2 \mathrm{~b}$ shows some swollen and leaked $\mathrm{ZC}$ niosomes after storage at $50^{\circ} \mathrm{C}$ for 120 days.

Figure 3 shows decrease trends of linear relationships between compound D remaining in the gels in closed containers and storage time, indicating that its degradation follows zero-order kinetics. Degradation rate constants of compound D stored at $4,25,45$ and $50^{\circ} \mathrm{C}$ were $0.50,0.68$, 1.67 and $3.28 \%$ day $^{-1}$ in $\mathrm{ZC}$ gel, and $0.07,0.08,0.30$ and $0.35 \%$ day $^{-1}$ in $\mathrm{ZC}$ niosomal gel, respectively.

Arrhenius plots (Fig. 4) show linear relationships between natural logarithms of degradation rates of compound $\mathrm{D}$ and the reciprocal of temperatures in the $\mathrm{ZC}$ gel $(r=-0.905)$

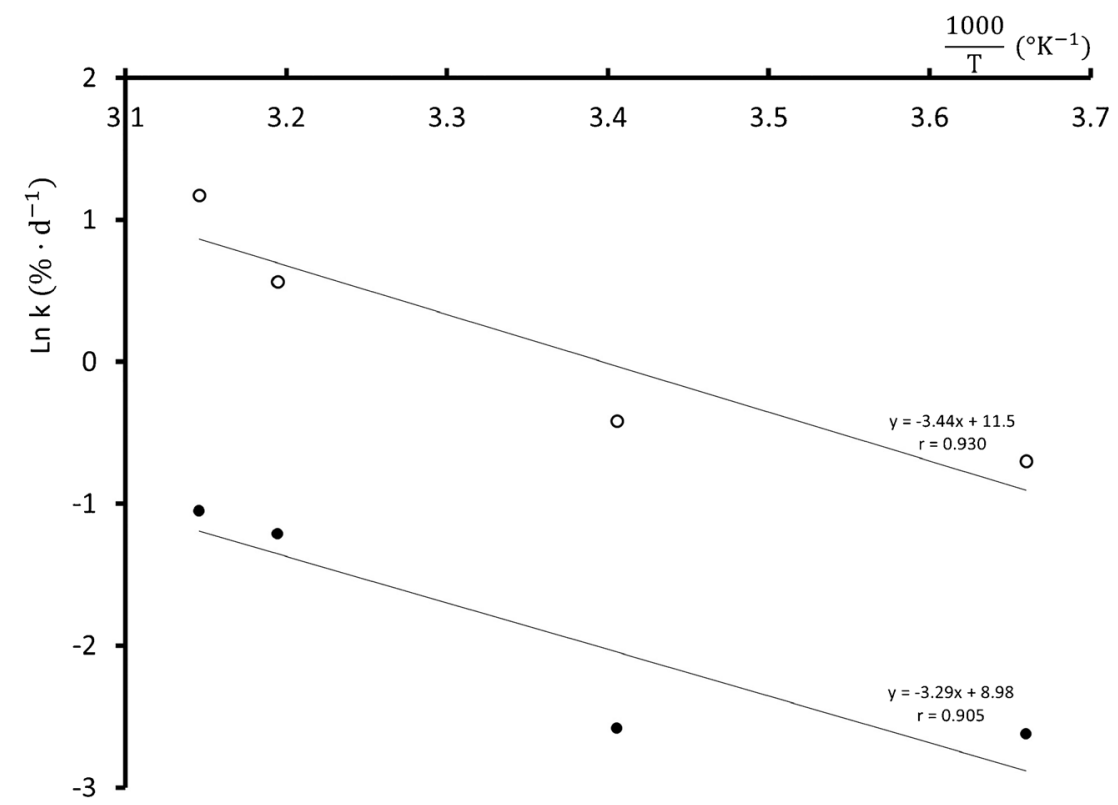

Fig. 4. Arrhenius plots between natural logarithm of degradation rate constants $\left(\right.$ day $\left.^{-1}\right)$ and the reciprocal of absolute temperatures of the storage conditions (K); $\mathrm{ZC}$ niosomal gel (empty circles), ZC gel (filled circles) and the Arrhenius equation (shown in Eq. 1) 

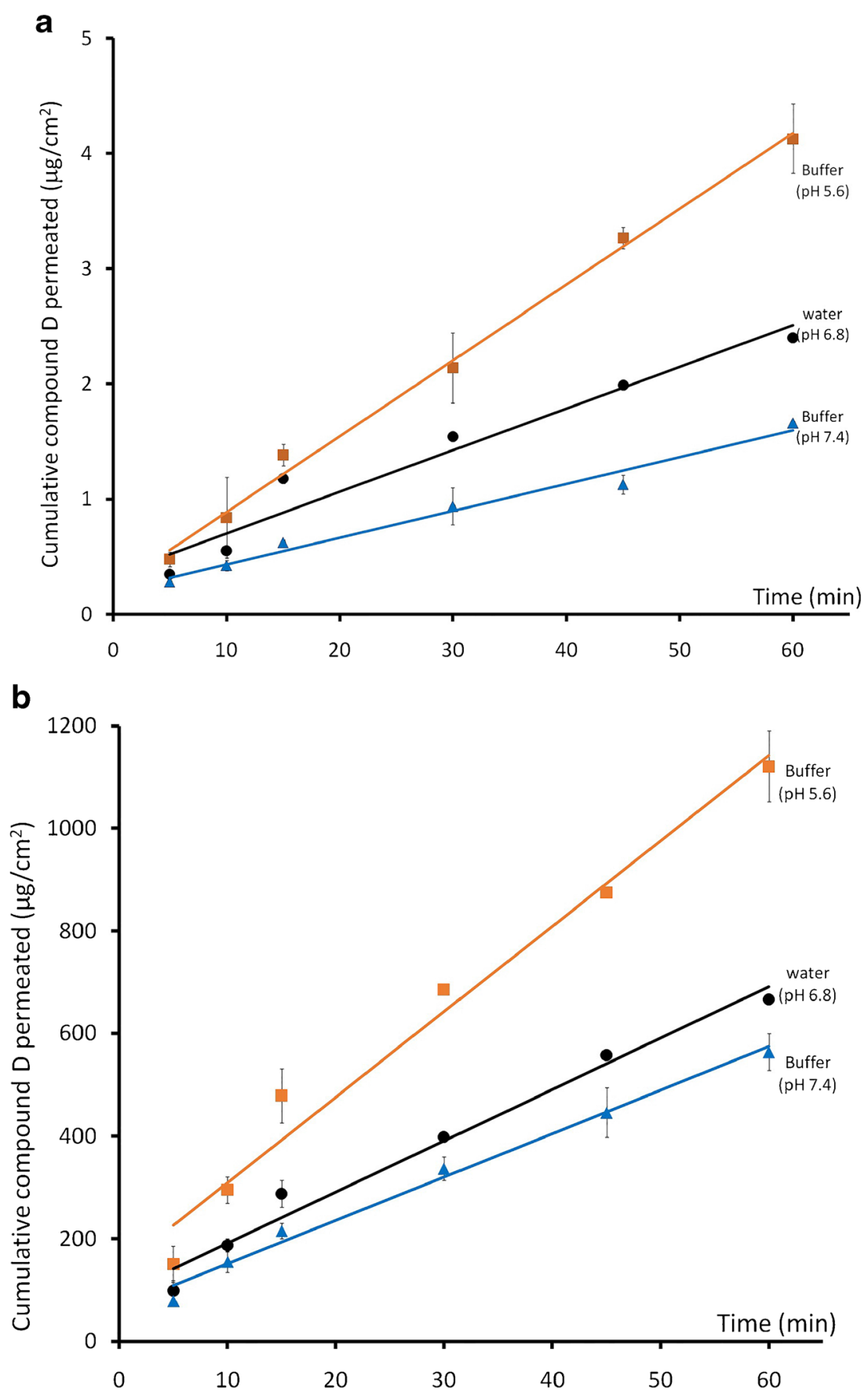

Fig. 5. In vitro permeation profiles of compound $\mathrm{D}$ from a $\mathrm{ZC}$ gel and $\mathbf{b} \mathrm{ZC}$ niosomal gel through porcine skin using sink conditions at $35^{\circ} \mathrm{C}$ into receptor solutions, citrate buffer at $\mathrm{pH} 5.6$ (orange cubes), deionized water at $\mathrm{pH} 6.8$ (dark circles) and phosphate buffer at $\mathrm{pH}$ 7.4 (blue triangles)

and the ZC niosomal gel ( $r=-0.930)$ with a parallel gap which defines about seven times higher degradation rates of compound D in ZC gel than that in ZC niosomal gel.

Compound D, from ZC gel (Fig. 5a) and ZC niosomal gel (Fig. 5b), readily and steadily permeated through porcine skin into buffers at $\mathrm{pH} 5.6$ and 7.4 and water $(\mathrm{pH}$ 6.8). There was little or no lag time, indicating that the permeation was dominantly a result of diffusion. ZC gel provides a lower permeation of compound D than ZC niosomal gel, although both gels were prepared with the same initial concentration of compound D. Its permeation fluxes from $\mathrm{ZC}$ gel into water at $\mathrm{pH} 6.8$ and buffers at $\mathrm{pH} 5.6$ and 7.4 were $0.04,0.07$ and $0.02 \mu \mathrm{g} / \mathrm{cm}^{2} / \mathrm{min}$, respectively $(p=0.025)$, while those from $\mathrm{ZC}$ niosomal gel into water of $\mathrm{pH} 5.6$ and 7.4 were 10.0, 16.7 and $8.5 \mu \mathrm{g} / \mathrm{cm}^{2} / \mathrm{min}$, respectively $(p=0.007)$. Figure 6 shows that an increase in the $\mathrm{pH}$ of receptor reduced compound $\mathrm{D}$ permeation in a linear trend, i.e. from ZC gel $(r=-0.998)$ and ZC niosomal gel $(r=-0.987)$.

Croton oil-induced ear edema was used to compare anti-inflammation activity of $\mathrm{ZC}$ niosomal gel, piroxicam 


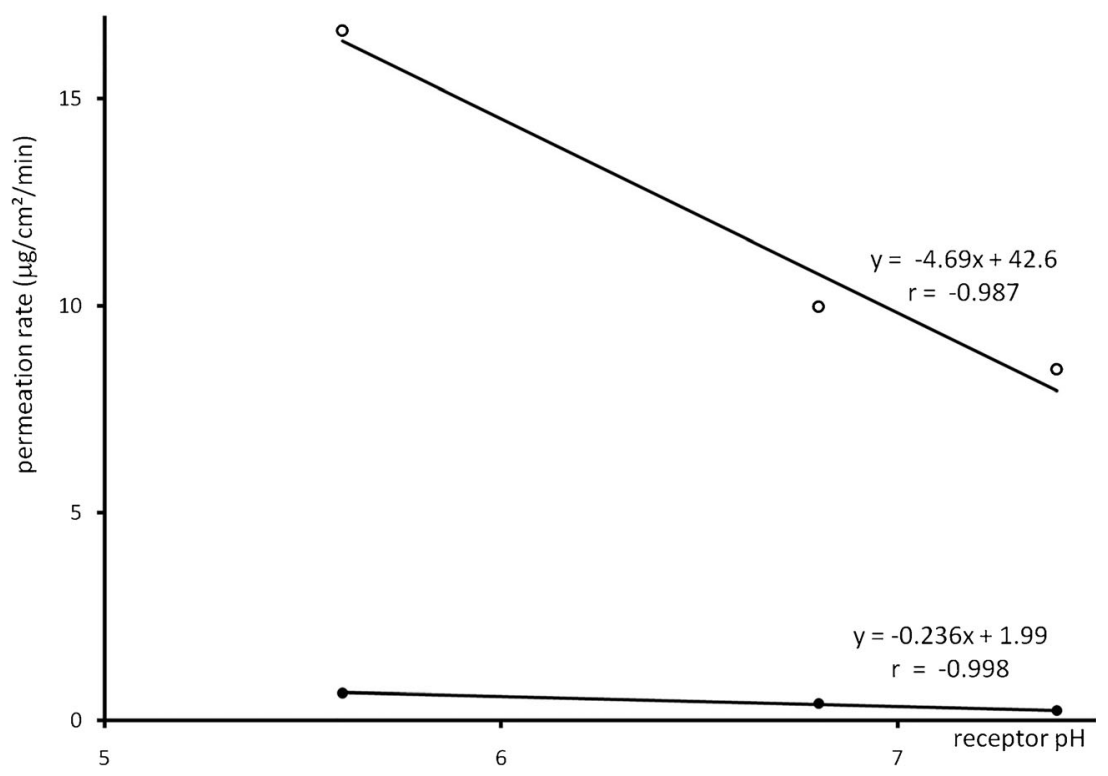

Fig. 6. Linear relationship between $\mathrm{pH}$ of receptor media and in vitro permeation flux $(\mu \mathrm{g} /$ $\mathrm{cm}^{2} / \mathrm{min}$ ); ZC niosomal gel (empty circles) and ZC gel (filled circles)

gel and hydrocortisone cream and shown as ear edema and inhibition in Fig. 7a. There is no significant difference in the overall ear edema inhibition among the mice topically applied with ZC niosomal gel, piroxicam gel and hydrocortisone cream $(p<0.05)$. Ear edema was gradually inhibited by ZC niosomal gel to reach its maximum inhibition of about $75 \%$ at $2 \mathrm{~h}$ after application and slightly decreased. Thus, topical anti-inflammatory effect of ZC noisome gel has been shown to be in line with piroxicam gel and hydrocortisone cream.

Changes in tail flick latency, which compares tolerance duration of typical tail-withdrawal reflex of the mice, before and after receiving topical applications of $\mathrm{ZC}$ niosomal gel, reached a maximum of about $80 \%$ at $2 \mathrm{~h}$. At $1 \mathrm{~h}, \mathrm{ZC}$ niosomal gel gave significantly higher (about $20 \%)$ tail flick latency changes than the other treatments $(p<0.05)$. However, the change with $\mathrm{ZC}$ niosomal gel applications was gradually decreased after $2 \mathrm{~h}$, but was not significantly different from that with piroxicam gel applications $(p>0.05)$. Hydrocortisone performed the worst in this test, due to its mild analgesic activity.

\section{DISCUSSION}

Since ZC could be affected by cultivation conditions (21) or genetic diversity (22), yields of compound D are monitored to assure product quality. The samples of ZC gave about $15 \%$ yields of compound D which were insignificantly different between the collections from dry and rainy seasons $(p>0.05)$. ZC gel and ZC niosomal gel were prepared to contain about $2 \mathrm{mg} / \mathrm{g}$ (or about $0.5 \mathrm{mg} / \mathrm{cm}^{2}$ ) of compound D. Despite the similar recovery, the coefficient of variation $(\mathrm{CV})$ of compound D contents in ZC niosomal gel was slightly higher than $\mathrm{ZC}$ gel as niosomes are small vesicular dispersion in viscous gel. The particle sizes of the ZC niosomes were polydispersed with an average diameter of approximately $1 \mu \mathrm{m}$. Attempts to measure sizes and size distribution of the $\mathrm{ZC}$ niosomes by dynamic light scattering did not obtain explainable results due to adsorption of polymers on the surface of the vesicles. Such adsorption, however, should provide 'protection' for vesicular aggregation and hold the niosomes in the gel.

\section{ZC Gel and ZC Niosomal Gel: Stability and Permeation}

It was surprising that degradation of compound $\mathrm{D}$ in both gels followed zero-order kinetics, indicating a concentrationindependent manner. Increasing the storage temperatures increases the degradation rates of compound $\mathrm{D}$ in $\mathrm{ZC}$ gel and $\mathrm{ZC}$ niosomal gel. The greater the temperature dependency of degradation rate, the greater is the activation energy $\left(E_{\mathrm{a}}\right)$, estimated from the slopes of the plots in Fig. 4 by Arrhenius equation (Eq 1). $E_{\mathrm{a}}$ of compound D were, thus, estimated to be 28.6 and $27.3 \mathrm{~kJ} / \mathrm{mol}$ for $\mathrm{ZC}$ gel and its niosomal gel, respectively. Arrhenius plots of curcumin in niosomes were also similarly parallel and comparable to solubilized form with an $E_{\mathrm{a}}$ of about $10 \mathrm{~kJ} / \mathrm{mol}$ (32). Also, intermolecular interactions between curcumin and cholesterol in the niosomal bilayer reduce thermal interference to the encapsulated curcumin. Similarities in chemical structures of curcumin and compound $\mathrm{D}$ lead to believe that compound $\mathrm{D}$ would have been interacted with the components within the niosomal bilayer. Enhanced stability of compound D by niosomal encapsulation is in line with the previous report (41).

From the same gel base, compound D permeation was profoundly affected by niosomal encapsulation and, to a lesser extent, by the $\mathrm{pH}$ of the receptor. The amphiphile structure of compound D, hydroxyl group at one end and methoxy groups at the other end along the phenyl group, could have facilitated its diffusion through the skin, and as a result, there was no observed lag time from both formulations. This finding resembles the rapid diffusion of compound D with no lag time (20). In contrast to the firstorder permeation kinetics of ZC extract in chitosan/PVA/ glycerin patches with burst effects of compound D (20), 

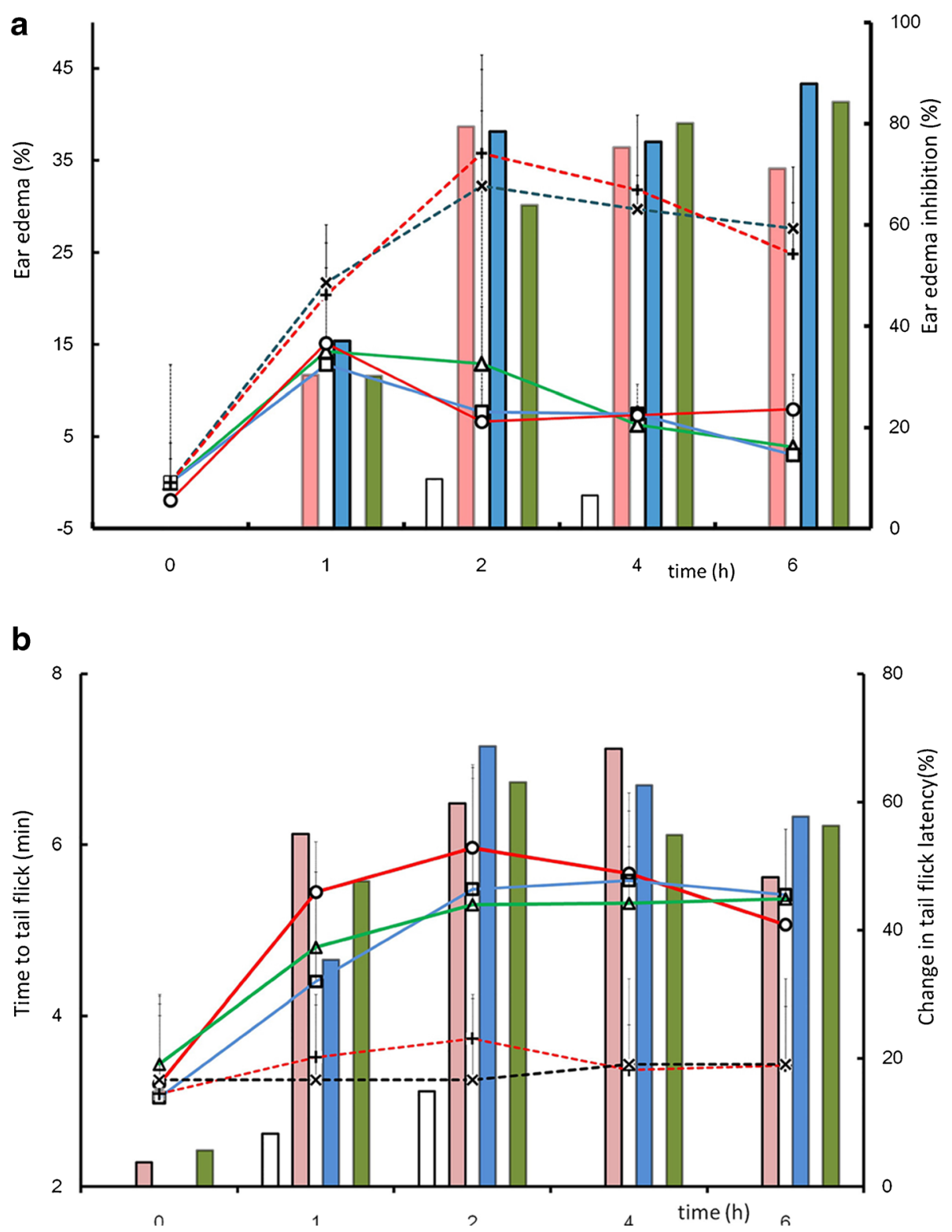

Fig. 7. Comparison of topical applications of ZC niosomal gel (empty circles), hydrocortisone cream (empty triangles), piroxicam gel (empty squares), blank niosomal gel (plus sign) and blank gel (multiplication sign) in mice with a croton oil-induced ear edema measured as inhibition of ear edema and $\mathbf{b}$ bars show time to tail flick ( $n=6$ each); error bars represent standard deviations

our niosomal gel with encapsulated compound D provided zero-order kinetics. This leads us to suggest that diffusion of compound D was affected by the positive charges of chitosan in the patches but not our gel formula. The receptor $\mathrm{pH}$ and permeation fluxes of compound $\mathrm{D}$ from both gels were linearly correlated, as shown in Fig. 6. A receptor $\mathrm{pH}$ of 5.6 gave 2-3-fold higher permeation rates than at $\mathrm{pH} 7.4$ which is the physiological $\mathrm{pH}$. Acid condition predominates the inflamed tissue loci and triggers related immune responses $(38,39)$. Receptor fluid at a $\mathrm{pH}$ of 5.6 aims to represent the skin $\mathrm{pH}$ of inflamed tissue $\mathrm{pH}$ with higher levels of hydrogen ions and may induce the hydroxyl group of the compound D to associate with water and thus facilitate diffusion and skin permeation. Enhanced permeation of compound D by niosomal encapsulation is in line with the previous report (42).

\section{In vivo Anti-inflammatory Activity}

For ethical reasons (35), ZC niosomal gel was selected to compare its activity with commercially available products and blanks in the animal studies based on in vitro permeation results and preliminary screening which indicated that $\mathrm{ZC}$ gel was insignificantly different from its blank gel. Blank niosomal gel is insignificantly different from blank gel in all tests, as shown in Fig. 7 ( $p>0.05$ both), indicating no antiinflammatory effect of the niosomes. Phenylbutanoids from ZC extract possessing anti-inflammatory and analgesic activities (17) are shown to be topically delivered by the ZC niosomal gel formulation to exert both activities in this study. 12-o-tetracanoylphorbol esters, the irritant of croton oil, cause vasodilatation within 1-2 h (36); as a consequence, increased 
blood flow and vascular permeability induce cyclooxygenase and lipoxygenase pathways of arachidonic acid metabolism (40). Anti-inflammatory and analgesic activities of ZC niosomal gel were observed as an immediate action with times to peak of 1 and $2 \mathrm{~h}$, respectively. Secondly, both activities slightly declined following the peak times but were maintained at similar extents to the positive controls for up to $6 \mathrm{~h}$ $(p>0.05)$. This could be the result of an immediate permeation and acidic $\mathrm{pH}$ preference with the niosomal encapsulation which localized the active phenylbutanoids. This is in line with the dermal pharmacokinetic study of $\mathrm{ZC}$ active phytochemicals which suggests the duration of action of $<2 \mathrm{~h}$ and a peak time at $1 \mathrm{~h}(37)$.

In vivo study confirms the immediate action of topically applied ZC niosomal gel at the target sites for inflammation and pain. Previous reports on in vivo anti-inflammatory administered crude ZC extracts by oral (17) or injection (23). The topical route provides substantial advantages over systemic administrations, for local effects. Some hydrogels can behave as burdens of skin permeation to hydrophobic compound(s). Thus, our in vitro and in vivo studies suggest that active ZC phytochemicals depend on delivery systems to exert topical activities. Herbal characteristics and yellow staining restrict the use of topical $\mathrm{ZC}$ products which indicates that high performance of product quality of ZC is required (20). Enhanced permeation and stability of compound D from ZC extract in a novel gel product with an emphasis on $\mathrm{pH}$ concerns from the present study was, thus, conclusive.

\section{CONCLUSIONS}

ZC niosomes coated with polymers with approximate sizes of $1 \mu \mathrm{m}$ were used to form niosomal gel which contained an average compound D content of about $2 \mathrm{mg} / \mathrm{g}$. Degradation rate of total compound $\mathrm{D}$, which was affected by storage temperatures, was significantly lower with niosomal encapsulation than non-encapsulation in the same gel base $(p<0.05$ all). In vitro skin permeation rate of compound $\mathrm{D}$ from the $\mathrm{ZC}$ niosomal gel was about 20-fold higher than the dissolved ZC gel. In vivo anti-inflammatory and analgesic testing in mice demonstrate the activities of ZC niosomal gel in comparison to piroxicam gel and hydrocortisone cream up to $6 \mathrm{~h}$. Topical gel formula of herbs like $Z$. cassumunar may require innovative approaches to guarantee product quality.

\section{ACKNOWLEDGMENTS}

Thailand Research Fund (MRG-WI53S026) and T.C. Pharmachem Co. Ltd. are thanked for the financial support. Dr. Jeffrey R. Johns is thanked for the English language editing and Vassana Netweera for the laboratory assistance.

\section{REFERENCES}

1. Moghassemi S, Hadjizadeh A. Nano-niosomes as nanoscale drug delivery systems: an illustrated review. J Control Release. 2014;185:22-36.

2. Mahale NB, Thakkar PD, Mali RG, Walung DR, Chaudhari SR. Niosomes: novel sustained release nonionic stable vesicle systems-an overview. Adv Colloid Interf Sci. 2012;183-184:46-54.
3. Kumar GP, Rajeshwarrao P. Nonionic surfactant vesicular systems for effective drug delivery_-an overview. Acta Pharm Sin B. 2011;1(4):208-19.

4. Agrawal R, Sandhu SK, Sharma I, Kaur IP. Development and evaluation of curcumin-loaded elastic vesicle as an effective topical anti-inflammatory formulation. AAPS PharmSciTech. 2014. doi:10.1208/s12249-014-0232-6.

5. Muzzalupo R, Tavano L, Cassano R, Trombino S, Ferrarelli T, Picci N. A new approach for the evaluation of niosomes as effective transdermal drug delivery systems. Eu J Pharm Biopharm. 2011;79:28-35.

6. Junyaprasert VB, Singhsa P, Suksiriworapong J, Chantasart D. Physicochemical properties and skin permeation of Span 60/ Tween 60 niosomes of ellagic acid. Int J Pharm. 2013;423:30311. doi:10.1016/j.ijpharm.2011.11.032.

7. Yeh MI, Huang HC, Liaw JH, Huang MC, Huang KF, Hsu FL. Dermal delivery by niosomes of black tea extract as sunscreen agent. Int J Dermatol. 2013;52:239-45.

8. Gupta NK, Dixit VK. Development and evaluation of vesicular system for curcumin delivery. Arch Dermatol Res. 2011;303:89101. doi:10.1007/s00403-010-1096-0.

9. Peppas NA, Bures P, Leobandung W, Ichikawa H. Hydrogels in pharmaceutical formulations. Eu J Pharm Biopharm. 2000;50:2746.

10. Alam MI, Baboota S, Kohli K, Ali J, Ahuja A. Pharmacodynamic evaluation of niosomal transdermal therapeutic gel containing celecoxib. Sci Asia. 2010;36:305-11.

11. Kumbhar D, Wavikar P, Vavia P. Niosomal gel of lornoxicam for topical delivery: in vitro assessment and pharmacodynamics activity. AAPS Pharma Sci Tech. 2013;14(3):1072-82. doi:10.1208/ s12249-013-9986-5.

12. Shahiwala A, Misra A. Studies in topical application of niosomally entrapped nimesulide. J Pharm Pharm Sci. 2002;5(3):220-5.

13. Gupta A, Singh S, Kotia NG, Webster TJ. Formulation and evaluation of a topical niosomal gel containing a combination of benzoyl peroxide and tretinoin for antiacne activity. Int J Nanomedicine. 2015;10:171-82.

14. Tuntiwachwuttikul P. Phenylbutanoids from Zingiber cassumunar. Phytochemistry. 1981;20(5):1164-5.

15. Ozaki Y, Kawahara N, Harada M. Anti-inflammatory effect of Zingiber cassumunar Roxb. and its active principles. Chem Pharm Bull. 1991;39(9):2353-6.

16. Masuda T, Jitoe A. Phenylbutenoid monomers from the rhizomes of Z. cassumunar. Phytochemistry. 1995;39(2):459-61.

17. Pongprayoon U, Soontornsaratune P, Jarikasem S, Sematong T, Wasuwat S, Claeson P. Topical anti-inflammatory activity of the major lipophilic constituents of the rhizome of Zingiber cassumunar. Part I: the essential oil. Phytomedicine. 1996;3(4):319-22.

18. Pongprayoon U, Tuchinda P, Claeson P, Sematong T, Reutrakul $\mathrm{V}$, Soontornsaratune P. Topical anti-inflammatory activity of the major lipophilic constituents of the rhizome of Zingiber cassumunar. Part II: Hexane extractives. Phytomedicine. 1997;3:323-6.

19. Panthong A, Kanjanapothi D, Niwatananant W, Tuntiwachwuttikul P, Reutrakul V. Anti-inflammatory activity of compound D \{(E)-4-(3',4'-dimethoxyphenyl)but-3-en-2-ol $\}$ isolated from Zingiber cassumunar Roxb. Phytomedicine. 1997;4(3):207-12.

20. Suksaeree J, Charoenchai L, Madaka F, Monton C, Sakunpak A, Charoonratana T, Pichayakorn W. Zingiber cassumunar blended patches for skin application: formulation, physicochemical properties, and in vitro studies. Asian J Pharm Sci. 2015. (in press) http://dx.doi.org/10.1016.j.ajps.2015.03.001.

21. Manochai B, Paisooksantivatana Y, Choi H, Hong JH. Variation in DPPH scavenging activity and major volatile oil components of cassumunar ginger, Zingiber montanum (Koenig), in response to water deficit and light intensity. Sci Hortic. 2010;126:462-6.

22. Kladmook M, Chidchenchey S, Keeratinijakal V. Assessment of genetic diversity in cassumunar ginger (Zingiber cassumunar Roxb.) in Thailand using AFLP markers. Breed Sci. 2010;60:412-8.

23. Chaiwongsa R, Ongchai S, Tangyuenyon S, Kontawelert P, Panthong A, Reutrakul V. Chondroprotective potential of 
bioactive compounds of Zingiber cassumunar Roxb. against cytokine-induced cartilage degradation in explants tissue. J Med Plants Res. 2012;6(39):5204-13.

24. Chaiwongsa R, Ongchai S, Boonsing P, Kongtawelert P, Panthong A, Reutrakul V. Active compound of Zingiber cassumunar Roxb. down-regulates the expression of genes involved in joint erosion in a human synovial fibroblast cell line. Afr J Tradit Complement. 2012;10(1):40-8.

25. Han AR, Jeong YH, Lee SK, Seo EK. Cyclooxygenase-2 inhibitory phenylbutenoids from the rhizomes of Zingiber cassumunar. Chem Pharm Bull. 2005;53(11):1466-8.

26. Waltenberger B, Schuster D, Paramapojn S, Gritsanapan W, Wolber G, Rollinger JM, et al. Predicting cyclooxygenase inhibition by three-dimensional pharmacophoric profiling. Part II: Identification of enzyme inhibitors from Prasaplai, a Thai traditional medicine. Phytomedicine. 2011;18:119-33. doi:10.1016/ j.phymed.2010.08.002.

27. Sukatta U, Rugthaworn P, Punjee P, Chidchenchey S, Keeratinijakal V. Chemical composition and physical properties of oil from ZC (Zingiber cassumunar Roxb.) obtained by hydro distillation and hexane extraction. Kasetsart J (Nat Sci). 2009;43:212-7.

28. Pithayanukul P, Tubprasert J, Wuthiudomlert M. In vitro antimicrobial activity of Zingiber cassumunar (Plai) oil and $0.5 \%$ Plai oil gel. Phytother Res. 2007;2(2):164-9.

29. Sunintaboon P, Pumduang K, Vongsetskul T, Pittayanuruk P, Anantachoke N, Tuchinda P. One-step preparation of chitosan/ sodium dodecyl sulfate-stabilized-oil-in-water emulsion of Zingiber cussumunar Roxb. oil extracts. Colloid Surf A. 2012;414:151-9.

30. Kaewchoothong A, Tewtrakul S, Panichayupakaranant P. Inhibitory effect of phenylbutanoid-rich Zingiber cassumunar extracts on nitric oxide production by murine macrophage-like RAW264.7 cells. Phytother Res. 2012;26:1789-2.

31. Suksaeree J, Charoenchai L, Pichayakorn W, Boonme P. HPLC method development and validation of (E)-4-(3,4dimethoxyphenyl)-but-3-en-1-ol in Zingiber cassumunar Roxb. from Thai Herbal Compress ball. Int J Pharm Pharm Sci Res. 2013;3(3):115-7.
32. Mandal S, Banerjee C, Ghosh S, Kuchlyan J, Sarkar N. Modulation of the photophysical properties of curcumin in nonionic surfactant (Tween 20) forming micelles and niosomes: a comparative study of different microenvironments. J Phys Chem B. 2013;117:6957-68.

33. Cilurzo F, Minghetti P, Sinico C. Newborn pig skin as model membrane in in vitro drug permeation studies: a technical note. AAPS Pharm Sci Tech. 2007;8(4) article 94.

34. Sekkat N, Kalia YN, Guy RH. Porcine ear skin as a model for the assessment of transdermal delivery to premature neonates. Pharm Res. 2004;21(8):1390-7.

35. Committee for the Update of the Guide of the Care and Use of Laboratory Animals (US); National Research Council of the National Academies (US). Guide for the care and use of laboratory animals. 8th ed. Washington DC: National Academies Press; 2011.

36. Tubaro A, Dri P, Melato M, Mulas G, Bianchi P, Negro PD, et al. In the croton oil ear test the effects of non-steroidal anti-inflammatory drugs (NSAIDS) are dependent on the dose of the irritant. Agents Actions. 1986;19(5/6):371-73.

37. Chooluck K, Singh R, Sathirakul K, Derendorf H. Dermal pharmacokinetics of terpinen-4-ol following topical administration of Zingiber cassumunar (plai) oil. Planta Med 2012. DOI http:// dx.doi.org/10.1055/s-0032-1315262.

38. Lardner A. The effect of extracellular $\mathrm{pH}$ on immune function. $\mathrm{J}$ Leukoc Biol. 2001;69:522-30.

39. Steen KH, Steen AE, Reeh PW. A dominant role of acid $\mathrm{pH}$ in inflammatory excitation and sensitization of nociceptors in rat skin, in vitro. J Neurosci. 1995;15(5):3982-9.

40. Young JM, Wagner BM, Spires DA. Tachyphylaxis in 12-otetradecanoylphobol acetate- and arachidonic acid-induced ear edema. J Invest Dermatol. 1983;80:48-52.

41. Rogerson A, Cummings J, Florence AT. Adriamycin-loaded niosomes: drug entrapment, stability and release. J Microencapsul. 1987;4(4):321-8. doi:10.3109/02652048709021824.

42. Rungpanichkul N, Nimmannit U, Muangsiri W, Rojsitthisak P. Preparation of curcuminoid niosomes for enhancement of skin permeation. Pharmazie. 2011;66570-575. doi: 10.1691/ ph.2011.1018. 